anatomy no less. In 1894 he discovered, in conjunction with Dr. George Oliver; the remarkable effects of intravenous injection of extract of the adrenal gland, tracing their source to the small medullary portion of the gland. This research proved the starting point for a great volume of work, and was followed by somewhat similar work on another ductless gland, the pituitary, which opened a modern chapter of physiological knowledge of that organ, again with important consequences to medicine.

The Rumford Medal is awarded to Mr. C. V. Boys. Mr. Boys has advanced physical science by producing apparatus for accurate physical measurements and by making measurements of a high order of accuracy. He invented the first method for producing quartz fibres and investigated their elastic properties; he showed that they were practically free from fatigue, and demonstrated how admirably suited they were for the measurement of very small forces. He measured the extremely minute forces due to the mutual attraction of small masses, and he made a torsion balance of beautiful design for measuring the constant of gravitation. He took the first photographs of a bullet in flight and studied the wave disturbances produced by them, and has made a series of researches on soap bubbles and films. Recently he has developed a gas calorimeter which is the standard instrument prescribed by the gas referees for ascertaining the calorific value of the gas supplies of towns, work of special appeal in regard to a medal commemorative of Count Rumford.

A Royal Medal is awarded to Sir Dugald Clerk. In I886, Sir Dugald described his experiments on the explosion of gaseous mixtures, providing data fundamental for the scientific development of internalcombustion engines. As chairman of the British Association Committee for investigation of gaseous explosions, he drew together workers concerned with the thermodynamics of internal-combustion engines who have contributed results of high importance. Sir Dugald himself investigated the effect of turbulence in a gas-engine cylinder and was successful in explaining the difference between the rate of combustion of the charge fired in a gas-engine cylinder in ordinary conditions of working, and the rate of combustion of the charge fired in a bomb. That to-day the internal-combustion engine is taking the place of steam power in smaller ships and in workshops as a prime mover of moderate power, and that to-day that engine renders possible the motor-car, the aeroplane and the submarine, is due largely to the scientific work of Sir Dugald Clerk.

A Royal Medal is awarded to Dr. Henry Hallett
Dale. Working with successive collaborators, Dr. Dale showed that histamine, an amine derived from ergot, produces a condition resembling wound shock and toxæmic collapse. By analytic experiments he succeeded in establishing that histamine, while causing spasm of arterial and visceral muscle, conversely paralyses the active contraction of the capillary bloodvessels; and this analysis was reached at a time when the property of contractility of those vessels had not been generally recognised. He showed that their paralysis is the dominant feature in the shock and is responsible for a virtual break-down of the whole blood circulation. He has shown further that in histamine "shock" we have a paradigm for the shock effect of a large class of protein poisons, and also for the grave condition known in medicine as secondary surgical shock, toxæmic collapse, and anaphylactic shock.

The Davy Medal is awarded to Prof. A. G. Perkin. Prof. Perkin is distinguished for his researches on the natural organic colouring matters. During the course of his researches on luteolin, morin, apigenin, quercitrin and other flavone compounds, he discovered and investigated certain derivatives which such dyestuffs form with acids-substances which he was able to employ for determining the molecular weights of these colouring matters. His classical researches on natural indigo have left few questions unanswered as regards the chemical constitution and behaviour of this important product, and he was the first to show that one of the constituents-indirubin-played no part during the process of vat dyeing with this agent. $\mathrm{He}$ was also the first to prepare in large quantity crystalline indican - the essential glucoside of natural indigo--and to study its properties. More recently he has investigated other natural products, notably the colouring matter of cotton flowers, and has dealt with the formation and structure of the important vat-dyes derived from benzanthrone.

The Darwin Medal is awarded to Prof. T. H. Morgan. Prof. Morgan's studies on polarity, on fertilisation, and later on gynandromorphism and sex determination, mark distinct advances in knowledge. The discovery of two kinds of spermatozoa in phylloxera and observations on chromosomes in these and other insects helped to elucidate the nature of the determination of sex in parthenogenesis. Of late years he has devoted himself to the study of heredity in various animals, and especially in the fly, Drosophila. The results obtained by him and his collaborators have thrown light on the relation of the factors of heredity to the chromosomes, on sex-linked and sexlimited characters, and other difficult problems in heredity.

\title{
University of Leeds.
}

Tribute to Prof. A. Smithells, C.M.G., F.R.S.

$\mathrm{T}^{\mathrm{H}}$ HE movement which was set on foot some time ago for signalising the distinguished services of Prof. Smithells to the University of Leeds, and in other directions, reached its culminating point on November 25, when a portrait of Prof. Smithells, painted by Mr. Fiddes Watt, A.R.S.A., was presented to the University at a ceremony held in the Great Hall. At the same time, it was announced that the fund had reached the sum of $2462 l$. $6 s$. I I $d$., of which approximately one half had been contributed by the gas industry, to which Prof. Smithells had been able to render such distinguished service.

The proceedings were opened by the pro-chancellor of the University, Mr. E. George Arnold, who spoke in the warmest possible terms of what Prof. Smithells had done during his 38 years' tenure of the chair of chemistry not only as professor of that subject but also in connexion with the wider matters of policy which the University had had to face at the time of its foundation and in the years that followed.

Mr. Arthur Lupton, who was pro-chancellor of the University during most of the long period of Prof. Smithells' service, presented the portrait on behalf of the subscribers, who numbered more than 800 . He was followed by Prof. J. W. Cobb, who supported Mr. Iupton in the presentation and spoke as an old student of Prof. Smithells and a colleague in the Senate and on the Board of Science and Technology. He pointed out that when it was decided to make Leeds a centre of university education, not merely was it that a new university was instituted but a new kind of university. Its distinguishing mark was that not only was science to have a place of honour, but that a Faculty of Technology was to be created

$$
\text { NO. } 2875 \text {, voL. I I } 4 \text { ] }
$$


in the University to rank along with the other Faculties of Art, Science, and Medicine, and to live alongside them in the closest intimacy. To do this effectively required judgment, imagination, and particularly courage and the faculty of dealing wisely with men and affairs. Prof. Smithells had written and spoken on this subject but always impersonally. On this occasion it was only proper that prominence should be given to the personal aspect, and the dominating part played by Prof. Smithells in this work fully and freely acknowledged.

Further support came from Prof. B. M. Connal, speaking as an old Arts colleague, and from Mr. J. Ferguson Bell, the president of the Institution of Gas Engineers, who, speaking for the gas industry, acknowledged the great indebtedness which they felt to science in application to their industry and particularly to the work of Prof. Smithells and the University of Leeds.

The portrait was received by the vice-chancellor on behalf of the University.

Prof. Smithells then described how his scientific work on flames had brought him into contact with the gas industry and its problems, and acknowledged, in impressive terms, its generosity to the University and the honour now paid to him. Referring to his colleagues, past and present, he paid a tribute to the founders of the old Yorkshire College and the remarkable group of men of science-Green, Rucker, Thorpe, and Miall - who in the early years so successfully disseminated the right spirit in the young institution, which ensured its initial success and later progress. To the late Prof. L. C. Miall he expressed a special personal tribute and the belief that no man did more for the spirit of the College and University. Speaking of the scholarship to be founded with the funds subscribed, he had wondered for a moment whether unity of knowledge might not receive appropriate illustration by devoting it to some literary end, but the idea was no doubt somewhat fantastic in this connexion. After all, he believed in science and shared the conviction expressed by a great man of letters, Mr. Galsworthy, that the future of the race was in the hands of science. It was right and proper, therefore, that this scholarship should be devoted to its advancement. In complimenting Dr. Baillie on his appointment as vice-chancellor, he assured him of a generous welcome, and expressed a firm faith in the modern university.

It was announced that the Smithells Fund would allow, after payment of the portrait and incidental expenses, of the establishing of a scholarship bearing the name of Prof. Smithells, within the University, of approximately rool. per annum.

\section{The British Dirigible Programme.}

THE decision to take up again the development of dirigibles in Great Britain has probably been influenced by the example of the United States.

The following table gives a basis of broad comparison with German craft:

\begin{tabular}{|c|c|c|c|c|c|c|c|}
\hline Name. & Length. & Diam. & Volume. & $\begin{array}{c}\text { Displace- } \\
\text { ment. }\end{array}$ & Power. & Speed. & $\begin{array}{l}\text { Length/ } \\
\text { Diam. }\end{array}$ \\
\hline $\begin{array}{l}\text { R ror } \\
\text { "Burney", } \\
\text { ZR } 3 . \\
\text { L } 59 . \\
\text { Bodensee }\end{array}$ & $\begin{array}{l}\mathrm{m} . \\
220 \\
212 \\
203 \\
226.5 \\
\mathrm{I} 2 \mathrm{I}\end{array}$ & $\begin{array}{l}\text { m. } \\
39 \cdot 9 \\
40 \cdot 5 \\
28 \\
23 \cdot 9 \\
18 \cdot 7\end{array}$ & $\begin{array}{r}\text { cub. m. } \\
\text { I } 43,000 \\
\text { r } 43,000 \\
70,000 \\
68,500 \\
20,000\end{array}$ & $\begin{array}{c}\text { tons. } \\
\text { I65 } \\
165 \\
81 \\
79 \\
23\end{array}$ & $\begin{array}{c}\text { k.w. } \\
7 \times 430 \\
7 \times 430 \\
5 \times 300 \\
5 \times 180 \\
4 \times 180\end{array}$ & $\begin{array}{l}\mathrm{km} / \mathrm{hr} . \\
\text { I } 5 \text { est. } \\
\text { I } 5 \text { est. } \\
\text { I } 40 \text { max. } \\
\text { I } 3 \text { I max. } \\
\text { I } 35 \text { max. }\end{array}$ & $\begin{array}{l}5 \cdot 5 \\
5 \cdot 25 \\
7 \cdot 25 \\
9 \cdot 5 \\
6 \cdot 45\end{array}$ \\
\hline
\end{tabular}

German practice shows much greater ratios of length/diameter; in the case of the L 59, this was perhaps due to the greater ease with which existing airsheds can be increased in length than in height and width; but the Bodensee, a successful post-War commercial craft, and the $\mathrm{ZR} 3$, the latest example of German design, were free from this restriction.

In passing from the $Z R_{3}$ to the $R$ Ior and the "Burney" the volume and power are both doubled, so that with similar shapes there should be an increase in speed of about $2^{1 / 9}=\mathrm{I} \cdot 08$, or from $\mathrm{I}_{4} \mathrm{O}$ $\mathrm{km}$. $/ \mathrm{hr}$. to $\mathrm{I}_{5} \mathrm{I} \mathrm{km}$. $/ \mathrm{hr}$., as compared with II $5 \mathrm{~km}$. $/ \mathrm{hr}$. which is a heavy margin in estimating. The shapes are, however, very different.

Tests at the National Physical Laboratory on relatively minute models in the wind-tunnel indicate a "best" ratio of length/diam. between 4.5 and 6 . Presumably the British designers are not relying solely on a very doubtful aerodynamical similarity, and it would be interesting to know the full size data on which they are departing so boldly from German practice.

The United States naturally hold for themselves the only supplies of helium, and the best method open to other nations for reducing fire risks is by installing heavy oil engines as is specified for the new British craft. The specification of "stainless" steel for the metal framework indicates a surprising advance in the design of members to resist local buckling in the very thin webs and flanges as compared with lighter and bulkier duralumin.

In a previous note (Nature, October II, p. 548), the useful life of a dirigible was estimated from German records as less than two serious voyages per month for eighteen months, excluding fire and war risks. It remains for time to show how far the $\mathrm{ZR} 3$ in American hands, and the new British craft in British hands, will compete with this standard of performance set up by the Germans after more than twenty years' experience.

No doubt it is difficult for the authorities to neglect completely a potential weapon, even though the aeroplane has proved an almost perfect antidote. From this point of view alone, their decision is entirely defensible. The long delay in coming to it may well be explained by the formidable nature of the problem taken as a whole.

\section{University and Educational Intelligence.}

CAMBRIDGE.-The time having lapsed during which the University can suspend the Jacksonian professorship of natural philosophy, and no new scheme for it having been adopted by the University, the Vice-Chancellor has declared that the professorship is vacant. An election will take place on January 5 next.

Mr. F. Balfour Browne, Gonville and Caius College, has been appointed University lecturer in zoology.

LONDON.-The title of professor of anatomy in the University has been conferred on Mrs. M. F. Lucas Keene, in respect of her post as head of the Department of Anatomy at the London School of Medicine for Women. Prof. Lucas Keene was appointed lecturer in anatomy and embryology, with charge of the department, at the London School of Medicine for Women in 1919, and the title of reader in anatomy in the University was conferred on her in respect of this post in I92 I.

A course of free public lectures on "The Anatomy and Physiology of the Sympathetic Innervation of the Striated Muscle " will be given at University College, at five o'clock on December 8, Io, and I2, by Prof. J. I. Hunter, of the University of Sydney. No tickets will be required.

Applications are invited for the chair of pathology at the London (Royal Free Hospital) School of Medicine for Women. Twelve copies of each appli-

NO. 2875 , voL. I I 4$]$ 